\title{
Color Terms and Verbal Signs in Women Skin Care Product Online Advertisement
}

\author{
Ferida Paxia Ichsan $^{1^{*}}$, I Made Rajeg ${ }^{2}$, Sang Ayu Isnu Maharani ${ }^{3}$ \\ English Department - Faculty of Arts - Udayana University \\ ${ }^{1}$ [paxia96@gmail.com] ${ }^{2}$ [made_rajeg@unud.ac.id] ${ }^{3}$ [isnu.maharani@yahoo.com] \\ *Corresponding Author
}

\begin{abstract}
The title of this study is "Color Terms and Verbal Signs in Women Skin Care Product Online Advertisement". The aims of this study are to find out the color terms and verbal sign, to describe the meaning and function of color and verbal signs, and their relationships that are found in three different women skin care product of the online advertisements. The data of this study were taken from three different websites of women skin care namely www.ponds.com, www.bioderma.com and www.laneige.com. Documentation method and the qualitative method were used in this study. There are three theories applied in this study, the first theory is theory of sign by Saussure cited in Chandler 2001 in order to analyze the meaning of color terms and verbal signs.The second theory is the theory of meaning and function proposed by Leech (1974) was used in order to find out the meaning and function of color terms' role and the verbal signs on each advertisement which also supported by the theory of color meaning symbolism proposed by Morton (1997). The results shows that there is a strong relationship between colors and verbal signs' role on each advertisement which supported by the model illustration in order to give impression for the readers to but the product.
\end{abstract}

Keywords: advertisement, color, verbal sign.

\begin{abstract}
Abstrak
Judul penelitian ini adalah "Color Terms and Verbal Signs in Women Skin Care Product Online Advertisement”. Tujuan penelitian adalah untuk mengidentifikasi istilah warna dan tanda verbal yang ditampilkan dalam tiga iklan online produk perawatan kulit wanita yang berbeda. Data dalam penelitian ini diperoleh dari tiga situs iklan online berbeda yaitu www.ponds.com, www.bioderma.com dan www.laneige.com. Dalam pengumpulan data, penelitian ini menggunakan metode dokumentasi dan metode kualitatif. Langkah-langkah untuk mengumpulkan data diawali dengan mengumpulkan data dengan mencari di internet. Selanjutnya, data yang telah memiliki komponen standar iklan, diklasifikasi untuk menemukan istilah warna dan tanda verbal. Tulisan ini menggunakan tiga teori, teori pertama yaitu teori tanda yang digunakan untuk menganalisis makna yang terdapat dalam tanda istilah warna dan tanda verbal yang dikemukanan oleh Saussure (Chandler 2001). Teori kedua yaitu teori makna dan fungsi oleh Leech (1974) yang digunakan untuk menemukan makna dan fungsi dari peran warna dan tanda verbal yang juga didukung oleh teori makna warna perlambangan oleh Morton (1997). Hasil dari penelitian ini menunjukan bahwa adanya hubungan kuat antara peran warna dan tanda verbal dalam iklan online pada produk perawatan wanita dengan didukung oleh ilustrasi model untuk memberikan kesan tertarik bagi para pembaca untuk membeli produk tersebut.
\end{abstract}

Kata kunci: iklan, warna, tanda verbal. 


\section{Background of the Study}

The definition of colour (Commonwealth English) or color (American English) is the human visual perception's characteristic which describes through color categories such as pink, red, blue, green and so on. In traffic light, we also know that Red means "stops" and green means "go". It means, color is already lodged in our minds and it delivers a message to someone who sees it. Wierzbicka (1996:287) stated that color is not a universal human concept but is correlated to the seeing which is considered universal, because the color is definable only via seeing. It can be created in all human societies, just as the concepts 'television', 'computer', or 'money' can, but despite the rapidly increasing contact between human societies.

As mentioned in Merriam Webster Dictionary, the definition of advertisement is a public notice like an announcement that published in press media or broadcast media. There are two kinds of the advertisement; there are printed media such as magazine, newspaper, book and broadcast media known as television, radio and internet website. Dyer (1982:120) stated that advertisements use color as an objective correlative where the product color, a packet of cigarettes, a cosmetic range and so on are echoed by its surrounding such as room decoration or even a natural setting by the clothes a model is wearing to the product.

\section{Problems of the Study}

a. What color terms and verbal signs are found in the women skin care product of the online advertisement? b. What meanings and functions are expressed by the colors and verbal signs found in the women skin care product of the online advertisement?

\section{Aims of the Study}

a. To find out the colors terms and verbal signs on each different women skin care product of the online advertisement.

b. To analyze the meaning and the function of colors and verbal signs in women skin care product of the online advertisement.

\section{Research Method}

The research method in this study consists of data source, method and technique of collecting data, and method and technique of analyzing data.

\subsection{Data Source}

There are three different online advertisements as the data source in this study. The first one comes from a brand of beauty and healthcare products owned by a parent company of the multinational corporation by Unilever, Pond's Age Miracle, which is available on www.ponds.com. Second, a French pharmaceutical company that specializes in medication for dermatological by Bioderma Laboratories, Bioderma Hydrabio Serum, which is available on www.bioderma.com. The last is South Korean brand skin care, Laneige, Laneige Water Sleeping Mask, which available on www.laneige.com. Those data were chosen because they contain many relevant data with the research problems about color terms and verbal signs. 


\subsection{Method and Technique of Collecting Data}

The method used in collecting data is the documentation method. The processes are first, found out the advertisement by searching on the internet. For instance, the advertisement was downloaded from different famous company in the world namely, French, Korea and the United State. Second, the data which contain colors and verbal signs were downloaded from the internet. Third, the detail information about the data was searched on the internet, journal and online articles. Finally, the data were classified based on their types using the related theory with a note taking technique.

\subsection{Method and Technique of Analyzing Data}

The collected data were analyzed using the qualitative method based on the theoretical framework. In this study, the collected data were analyzed used the theory of Sign proposed by Chandler (2001) in order to get the visual aspect and the theory of meanings of color and color symbolism proposed by Morton (1997) in order to get the meaning of each color. For the verbal signs, a theory of Meaning and Function proposed by Leech (1974) was used. The meaning and function of verbal signs and colors were used to find out the relationship between color terms and verbal signs on each different products based on the research problems.

\section{Analysis}

\subsection{Identification of Color Terms and Verbal Signs in Women Skin Care Product of the Online Advertisement}

This part consists of the analysis of color terms and verbal sign of "Pond's Age Miracle" advertisement.

\subsubsection{Color Terms}

There were five colors appeared in "Pond's Age Miracle" advertisement. There were white, pink, red, black and grey.

\section{a. White}

The white color was used in advertisement 1 as the color of model's dress, the color of model's necklace, the model's skin, and as in the verbal sign. White is one of the kinds of basic color terms proposed by Wierzbicka (1996). According to Wierzbicka (1996), when people see something, for instance, seeing the light of the sun, he or she can think that the color of an object that they see is white. The white color itself represents purity, cleanliness, truth, innocence, chastity, spirituality, sophistication, refinement, newness, blandness, and sterility. By using the white color, the viewers can directly get the attention and desire to buy this product and get a significant benefit. It also displayed clearly that the white color could grab people's attraction because it relates to innocence and new beginnings so that the viewers can understand easily the verbal aspect message.

Furthermore, as it can be seen in the color of the model's skin, model's dress color and the color of model's necklace, it signifies that white was a purity because it can be seen from the result of model's final result on the picture after applying the moisturizer which was she is smiling instead of pulling down her lip corners and her eyes reflected happiness rather than dropping her upper eyelids down because now she feels more confident. Also, according to Meriam Webster Dictionary, the word purity means the state of being pure and lack of harmful or dirty substance. So, it means in this advertisement this model clearly showed the result of applying Pond's Age 
Miracle moisturizer on the face was free from any blemish or spot and that's why the model looks younger than her age.

b. Pink

It signifies the pink color is youthful because it shows the happiness of woman who tends to have an inner beauty after applying this moisturizer and she feels happier because she looks younger as it can be seen in its softer shades on the texture of the cream which gave a good result for the consumers. Pink color occurred in the model's lip color, it represents as youthful and intended to produce an effect of calming for someone. So, the advertiser wanted to create the impression of comforting which is very appropriate to be used in this skin care women product which is able to grab consumer's attention.

c. Red

The red was color used in advertisement 1 as the color of the main product color's product package and as the main color of the advertisement. In advertisement 1 , it signifies that red is power and is the most striking color, often seen by the eye, excites the potential purchaser and even it stimulates the sense. It shows that red color represents power as it give energy to women to be more confident in her middle-aged to be still beautiful. This reason was also supported by the definition of power by Merriam Webster Dictionary that said it is an ability to produce an effect.

d. Black

The black color was used in advertisement 1 as the color of the model's hair, model's eyebrow and eyelash and model's eyelid. It signifies that black is strong which can be seen from the black color in this advertisement such as model's hair, model's eyebrow and eyelash, and model's eyelid. It can be said that black color represents the most prominent color for Asian tribes like Indonesian, Chinese, or Thailand which represents the identity the color of the model's hair who represents Asian hair. Basically, Pond's worldwide sold worldwide but Asian people tend to buy this product regularly so that's why one of the purposes of the advertiser is make the advertisement looks more captivating in order to get consumer's attention.

e. Grey

The grey color was used in advertisement 1 as the color of the bottom text and the background of the text. It signifies that the advertiser wanted to create modernity. Modernity means the state of being modern. It is related to the newest technology as it represents the best invention invented by Pond's company with their best formula such as Retinol which used in this skin care product.

\subsubsection{Verbal Signs}

a. Headline

The headline is "Look up to 10 years younger!".

b. Body Copy

The body copy is "See significant improvement in just 7 days!."

c. Signature Line

"NEW", "POND'S", and "age miracle"

d. Standing Details

"FORMULATED BY POND'S
INSTITUTE".




\subsection{Meaning and Function of Color Terms and Verbal Sign in Women Skin Care Product Online Advertisement}

There was found the coherence between color terms and verbal sign in the "Pond's Age Miracle" advertisement. The verbal sign in this advertisement was dedicated to all women especially those who are in the middle-aged because by applying this moisturizer on the skin, the consumer will look up ten years younger in just seven days as the formula of the cream comes from the best ingredient such as Retinol which is able to help to get a healthier skin. Also, it clearly supported by the visual sign of the picture of a middle-aged woman who looks younger which no wrinkles founded on her face skin and she looks very happy with her smiling smile on her face.

Besides, the color usage of the headline, body copy, and signature line were written with white color in order to presents the strength of the moisturizer's formula to increase the purchaser's desire to buy this skincare product. Also, the red color represented as a strong color for women to become more confident while using this product.

It can be concluded that there was a strong relationship between color terms and verbal sign. Both of them indicated as satisfied and confident. The picture in this advertisement clearly showed how the model feels confident and satisfied after using the product also the function of the verbal sign is to deliver the selfconfident from Pond's Age miracle moisturizer.

\section{Conclusions}

The color and the use of verbal sign play an important role in marketing and advertising, this study also found that there is a strong relationship between color terms and verbal signs in online advertisement as it can be seen from the company use a creative way through color to perceive a brand's personality itself because it can stir people emotions and increase purchases also to convey the message behind the meaning of the advertisement.

\section{Bibliography}

Chandler, D. 2001. Semiotica Para Pricipiantes (Semiotic For Beginner).

Dyer, G. 1982. Advertising as Communication. London: Routledge.

Leech, G. 1972. English in Advertising: A Linguistic Study of Advertising. London: Longman Group Limited.

Leech, G. 1974. Semantics: The Study of Meaning. Great Britain: Penguin Books.

Merriam Webster Online Dictionary. Color Definition. Available from: https://www.merriamwebster.com/dictionary/color.

Wierzbicka, Anna. 1996. Semantic Prime and Universals. New York: Oxford University Press.

Morton, Jill. 1997. Color Voodoo \#1: A Guide to Color Symbolism. Colorcom. 